\title{
Priorities for development on a wet coastal Bay of Plenty conversion property
}

P. LIVINGSTON and R. KYLE MAF Technology. PO Box 951, Rotorua

\begin{abstract}
Dairy conversion units are as individual as the persons operating them. The need for flexibility in planning is easily demonstrable. Less than 6 months after purchasing a second-year conversion property near Edgecumbe the owners discovered a need to review fully the goals and objectives encompassed in their management plan. Such a move had been "forced" upon them for several reasons, primarily:

(i) an announcement that milk solid (fat and protein) returns could be up to $25-30 \%$ lower than initially anticipated and

(ii) thepromptrecognition thatpastureperformance reflected much greater variation than earlier thought.
\end{abstract}

Short- and medium-term goals were reviewed, resultinginashiftinpriorityfrompasturerenovation and increased stocking rate to additional drainage and fertiliser. The confidence to make such changes was provided through a decision-making process classed as "whole-farm technology transfer". Decisions that affect one component of the dairy production system are not made in isolation from the effects on another. Decision-making on this property is a stepwise, consultative process based on objective rather than subjective means and focuses on the 'wider vision' of the property owners.

Keywords decision-making. goals and objectives, dairy conversion, whole farm technology transfer, management support

\section{Introduction}

The challenge to succeed in farming has never been greater. Success can be measured in many different ways and as such will vary from farm to farm, and from farmer to farmer. Accordingly, each production unit can be seen to have unique goals and objectives

In the Bay of Plenty/Rotorua region some 40 properties (pers. comm., Bay Milk Products Limited,
New Zealand Dairy Group) have been converted to dairying in the last three seasons. Depending on the availability of finance, the economics of various enterprise options and industry acceptance, a significant additional number could be expected to convert over the next three to five seasons.

The success of the recent conversions has been quite varied, particularly with regard to the ability to continue the development progrsmmes already in place. In the face of lower expected dairy revenue, the immediate reaction of many in the industry was to reduce inputs to survive (MAF Farm Monitoring Report June 1991). However, a longer-term analysis of the 'whole' production system may have, for many, meant that re-prioritising inputs were equally appropriate to adopting short-term survival tactics.

\section{Background}

Much of the lower-lying land at the northern end of Sutherland Road, west of Edgecumbe. was developed fromswampduring the 1970 s andprogressively converted to dairying.

The 68 ha property of Mr and Mrs D. by de Ley was first set up as a dairy unit in the $1989 / 90$ season by the previous owner. After their purchase of the property in 1990 the by de Leys developed a 5- to 7-year business plan that formally set objectives and targets for the goals of:

\section{(i) Leisure time \\ (ii) Financial security \\ (iii) Management/ production status.}

Production in Year one was $15 \%$ behind target, at $25500 \mathrm{~kg}$ milkfat ( $155 \mathrm{~kg} / \mathrm{cow}$ ) and $44000 \mathrm{~kg}$ total solids $(645 \mathrm{~kg} / \mathrm{ha})$. To achieve one of the 5 -year objectives. $35000 \mathrm{~kg}$ milkfat (60 $000 \mathrm{~kg}$ total milk solids) from 200 cows, the need for a number of previously unplannedinputs was promptly recognised.Additional formal planning that averted decision-making based on incomplete information was implemented. This process is referred to as management or decision support. 
Two main factors combined to drive the need for a full review, namely:

(i) $2530 \%$ lower revenue expectations for the $1990 / 91$ season.

(ii) an early recognition that pasture performance reflected greater variation than earlier predicted.

\section{Property details}

The property's elevation above mean sea level ranges between $2.5 \mathrm{~m}$, adjacent to the Tarawera River stop bank, to $1.5 \mathrm{~m}$ adjacent to the primary drainage outlet for this area. Tidal fluctuations combined with very low canal gradients do not permit an adequate level of ground-water for pastoral production to be maintained without the use of a drainage pump.

The soils (a complex of Awakeri sandy loam on shallow peat, Rangitaiki soils and Awaroa soils) (Pullar 1984) are geologically young and all contain coarse pumice sand lenses with thin layers of peat. Vertical ground-water movement is often impeded, giving rise to frequent and persistent surface ponding of rainfall.

An analysis of thenutrient status suggested phosphate levels were low in relation to future production aims. Olsen $P$ levels were 15-30 on the Awakeri sandy loam and 45-48 on the Rangitaiki and Awaroa soils. Maintenance fertiliser inputs equivalent to $500 \mathrm{~kg} / \mathrm{ha}$ of $30 \%$ potassic super-phosphate were derived from MAFTech's fertiliser model.

The pastures are open and typically characterised by a mixture of species found on low fertility sites and able to withstand frequent, heavy soil wetting. Ryegrass and white dover persistence was likely to be low, given the prevailing environmental conditions (Thorn, Roberts 1990. 1991, pers. comm.).

Pasture production was measured in Year one at
7000-8000 kg DM/ha, which compares with a 5-year average (1978-83) from the nearby Omeheu demonstration farm of $10500 \mathrm{~kg}$ DM/ha (Greig \& Allen 1978-83). Pasture utilisation was mostly subject to factors determined by soil moisture levels.

\section{Whole farm technology transfer}

The approach to decision-making on this property is referred to as 'management or decision' support. This is:

An integrated approach to objective decisionmaking aimed at achieving highly motivating dairy management systems.

The main features are that it is:

* Focused on goals/ objectives

* Farmer/ farm specific

* Results orientated

* Objectively based

* Proactive rather than reactive

* Enhances confidence (monitors decisions)

The Dairy Production system model (Figure 1) varies from property to property and farmer to farmer. The model shows the relationship between the various components of the business. Driven by farmers' goals and vision, decisions made on any one component, for example, animal nutrition, fertiliser or the need for labour, are always viewed in relation to the likely effect on all else.

The features of the management support concept are borne out in the formalised pathway of analysing decisions for any component. Figure 2 depicts the stepwise process used.

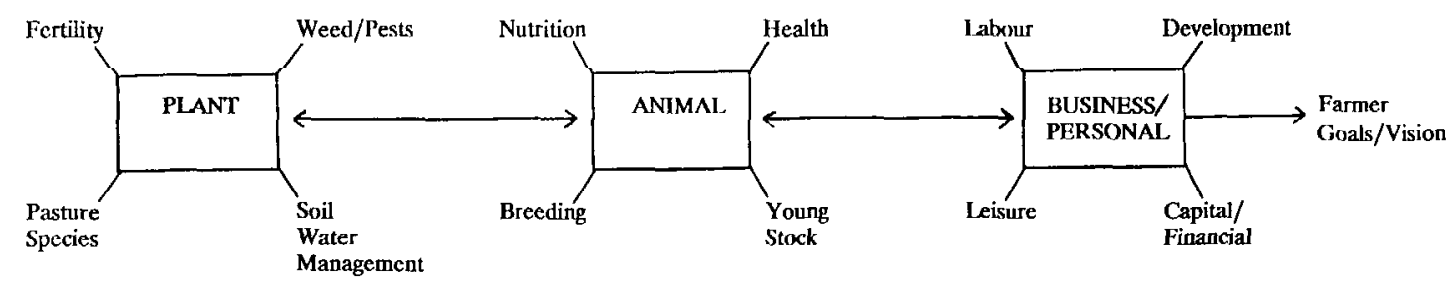

Figure 1 Dairy production system model 


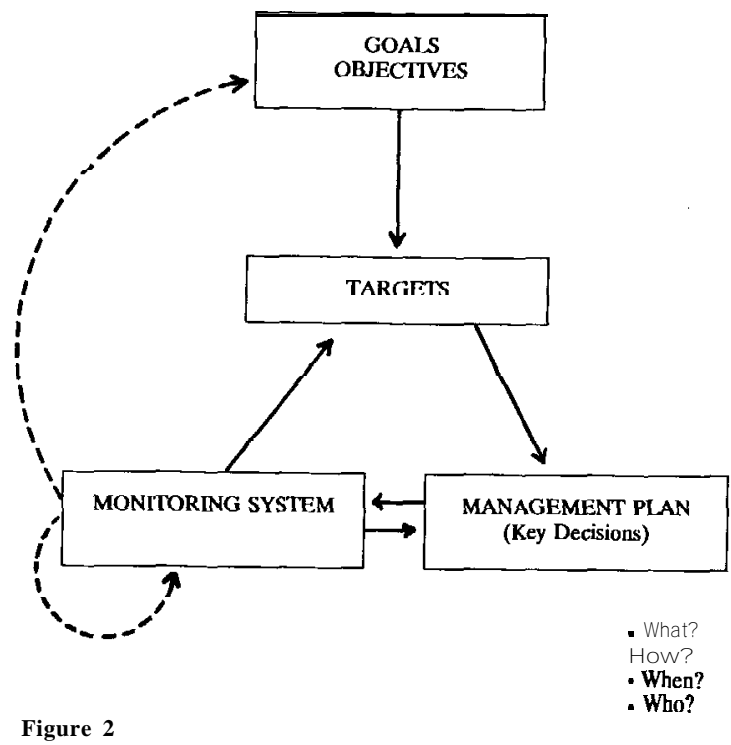

\section{Development priorities}

Debt reduction, pasture renovation and increased cow numbers were the initial focuses for capital expenditure, with other farm inputs budgeted at maintenance levels. The first reaction was to aut expenditure to survive, but closer analysis suggested that a transfer of capital to drainage and additional fertiliser would be more appropriate.

\section{Short term priorities}

\section{(a) Drainage development options}

The effects of imperfect drainage were in evidence in areas not adequately serviced by the drainage pump, and where the internal drainage system was not able (in terms of depth or intensity) to remove drainage water rapidlyenough. Theseeffectsincluded pastureyellowing, dieoff and the ingress of species synonymous with wet soil conditions.

\section{Summary of drainage development options}

A review of the current pumping capacity in relation to the area serviced indicated that the $28 \mathrm{~mm}$ per day coefficient for pastoral drainage was capable of being achieved, and that the poor drainage observed was not a result of current pumping station limitations.

Improving andintensifying thenetworkof theinternal drainage system was the next alternative Consideration was given to the use of subsurface drainage pipes as an alternative to openchannels. However, the unstable and

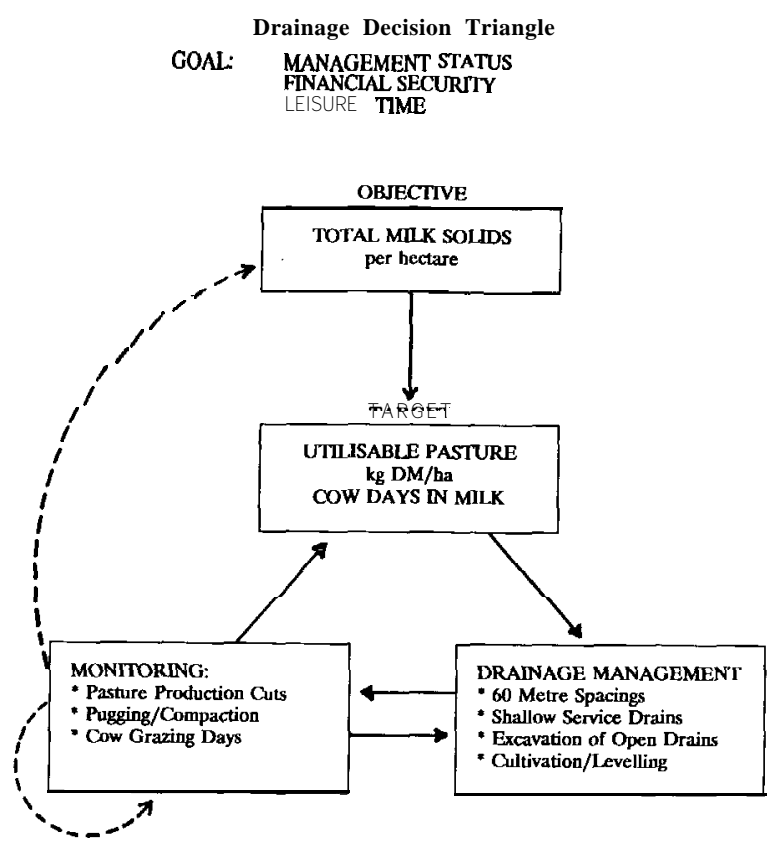

unpredictable soil conditions combined with inadequate gradients for economic performance precluded their application.

\section{(b) Fertiliser input options}

MAFTechnology's fertiliser requirement model suggested amaintenancenutxient input equivalent to 500 $\mathrm{kg} 30 \%$ potassic superphosphate perhectare. The financial downturn threatenedthe ability to apply this amount, A review of optimalOlsen Plevels(Roberts 1990.1991) to achieve pasture production in line with that needed for 5year production targets suggested these should be raised to 25-30 on the gley (Awakeri sandy loam) and 50-60 on the pumiceous soils (Rangitaiki and Awaroa soils). In such a situation withholding fertiliser was expected to decrease pasture production (Roberts et al. 1991).

By the end of the current season an additional input (capital dressing) of $1000 \mathrm{~kg} / \mathrm{ha}$ of $15 \%$ potassic superphosphate over a 2-year period will have been made, rather than the initial plan to apply the extra fertiliser over a longer timespan. In addition, the strategic use of nitrogen continues to be an important tool particularly with the poorly developed nitrogen cycle likely to be in operation on such a property (Roberts 1991 pers. comm.).

An appropriateriskmitigationprogramme is being implemented to account for the wide fluctuations between pasture supply and demand in the spring/ summer period. 


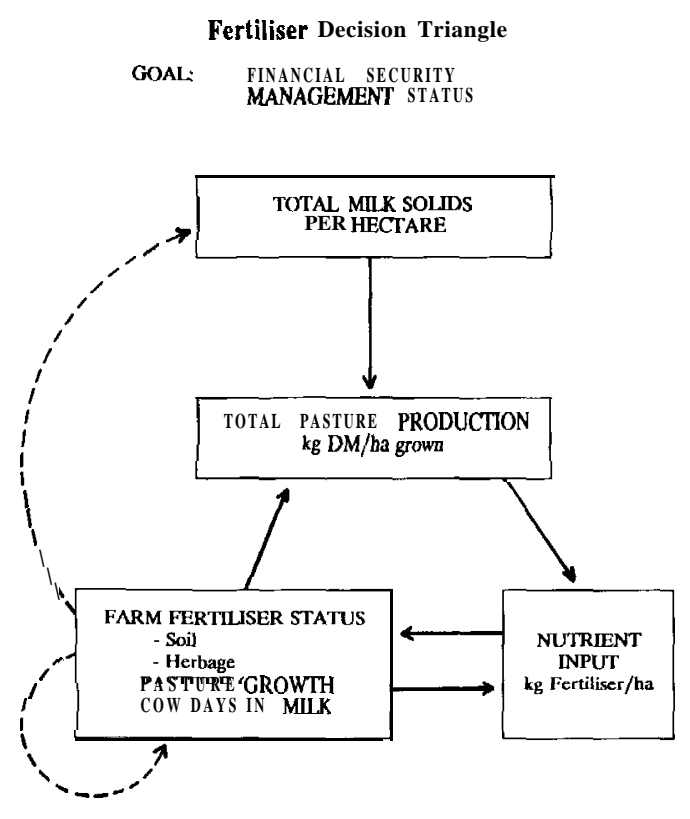

Medium term priorities

(a) Stocking rate

The additional emphasis placed on the above two inputs does not mean others have been forgotten. Stocking rate is much more likely to remain comparatively stable at 2.5-2.7 cows/ha for the next two years. This is considered by the management team to be relatively high to current pasture production (Simmonds 1991). Further reviews will be made with the intention of increasing to 2.8-3.0 cows/ ha in the medium term.

\section{(b) Pasture renovation}

Fourteenhectares of pasture wererenovatedlast autumn. Potential benefit, in terms of the distribution of feed supply, from the use of a proportion of short-term rotation ryegrass (Concord) has been incorporated (Percival et al. 1989). This is at the expense of sowing solely with perennials such as Yatsyn for which soil conditions more appropriate forplant persistenceneed to be established first (Thorn, Roberts pers. comm. 1990).

\section{Summary}

* A formal approach to objective decision-making has been adopted to take account of both long and short term goals.

* Continual reassessment of the actual and likely results has suggested that significant changes in development priorities were possible in the face of arecognition of lowered short term revenue targets.

* Such an approach has wider implications for farmers at all levels of the industry.

\section{ACKNOWLEDGEMENTS}

The authors wish to thank Duncan and AnneJanette by de Ley for their support, Pat Kilgarriff and Martin Hawke for technical support.

\section{REFERENCES}

Greig and Allen, Feed Budgeting, MAF Internal Publication.

Percival et al. 1989. Production andpersistenceof shortterm ryegrasses in the northern N orth Island. Proceedings of the NZ Grassland Association 50: 237-242.

Pullar W.A. 1984. Soil Map of Rangitaiki Plains, North Island New Zealand. N ew Zealand Soil Map Bureau Map 209. Part of New Zealand Soil Survey Report 86.

Roberts et al. 1991. The importance of fertiliser for milk production. Runkura Farmers Conference, 1991.

Simmmonds, J. 1991. Does reduaing stocking rate pay? Ruakura Farmers Conference, 1991. 